\title{
Effects of upstream hydropower operation and oligotrophication on the light regime of a turbid peri- alpine lake
}

\author{
Journal Article \\ Author(s): \\ Jaun, Lorenz; Finger, David; Zeh, Markus; Schurter, Michael; Wueest, Alfred \\ Publication date: \\ 2007-06 \\ Permanent link: \\ https://doi.org/10.3929/ethz-b-000066934 \\ Rights / license: \\ In Copyright - Non-Commercial Use Permitted \\ Originally published in: \\ Aquatic Sciences 69(2), https://doi.org/10.1007/s00027-007-0876-3
}




\title{
Research Article
}

\section{Effects of upstream hydropower operation and oligotrophication on the light regime of a turbid peri-alpine lake}

\author{
Lorenz Jaun ${ }^{1}$, David Finger ${ }^{1,2, *}$, Markus Zeh ${ }^{3}$, Michael Schurter ${ }^{1}$ and Alfred Wüiest ${ }^{1,2}$ \\ ${ }^{1}$ Surface Waters - Research and Management, Swiss Federal Institute of Aquatic Science and Technology, \\ Eawag, CH-6047 Kastanienbaum, Switzerland \\ ${ }^{2}$ Institute of Biogeochemistry and Pollutant Dynamics, ETH Zürich, CH-8092 Zürich, Switzerland \\ ${ }^{3}$ Laboratory for Water and Soil Protection of the Canton of Bern (GBL), Schermenweg 11, CH-3014 Bern, \\ Switzerland
}

Received: 2 August 2006; revised manuscript accepted: 26 February 2007

\begin{abstract}
Anthropogenic activities in catchments can alter the light regimes in downstream natural waters, affecting light attenuation and the perceived optical properties of the waters. We analyzed the effects of upstream hydropower operation and oligotrophication on light attenuation and reflectance in Lake Brienz (Switzerland). For this purpose, we reconstructed its light regime for the pre-dam condition and for periods of 4-fold increased primary productivity, based on direct observations of light and beam attenuation as well as concentrations of optically active compounds, especially observed and simulated
\end{abstract}

mineral particle concentrations. Based on our assessment, light attenuation before the construction of upstream dams was double the current value during summer and nearly half in winter. This result is consistent with pre-dam measurements of Secchi depths in the early 1920s. Using a simple optical model, a significant increase in reflectance since the 1970s was estimated, assuming a 4-fold decrease of optical active organic compounds within the lake. As reflectance is perceived by human eyes as turbidity, this may explain subjective reports by local residents of increasing turbidity in recent years.

Key words. Downstream effects; inorganic particles; light attenuation; reflectance; turbid lake.

\section{Introduction}

Sunlight is the primary energy source for biological production, providing the basis for aquatic life. In aquatic systems light availability is a critical boundary condition affected by both autochthonous (in situ produced) constituents and allochthonous substances from catchments. Phytoplankton and associated substances can determine the optical properties in the

* Corresponding author: phone: +41413492201 ;

e-mail: david.finger@eawag.ch

Published Online First: June 6, 2007 open ocean (Gordon and Morel, 1983; Morel, 1988). In contrast, inland and coastal waters are influenced by various optically active constituents defining the "multicomponent" water (see below; Arst, 2003).

Light attenuation and the appearance of lake waters are sensitive to anthropogenic activities in their catchments (Swift et al., 2006), such as particle input due to erosion (Effler et al., 2001) or mining (DaviesColley et al., 1993; Guenther and Bozelli, 2004). These changes may lead to ecological effects including reduced primary production due to light limitation (Jewson and Taylor, 1978; Krause-Jensen and SandJensen, 1998) and lower visibility, thereby affecting 


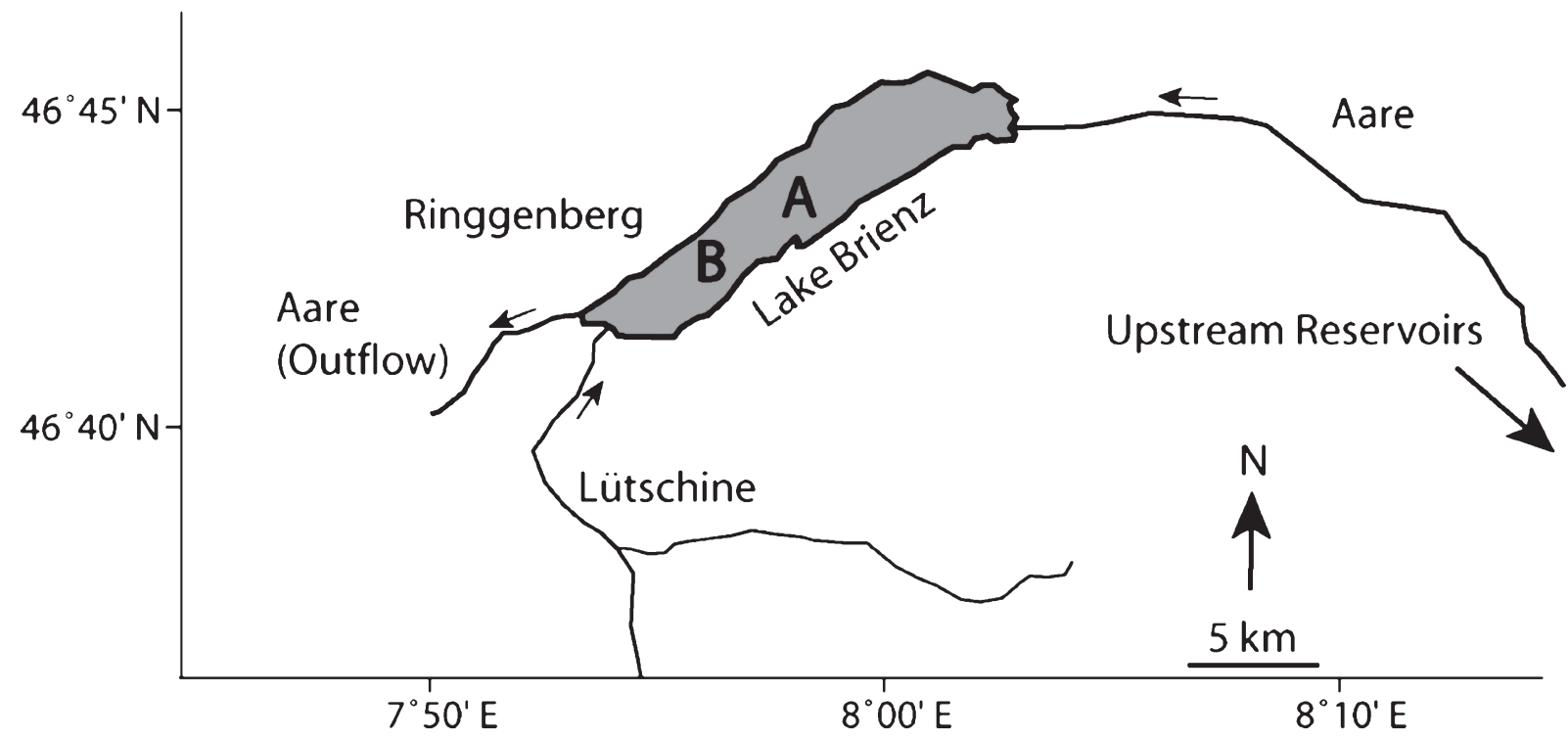

Figure 1. Map of Lake Brienz and inflows Lütschine and Aare. Hydropower reservoirs are located $\sim 30 \mathrm{~km}$ upstream of Aare inlet. A denotes the deepest location where most sampling took place (CH coordinates: 640.235/175.139). B indicates site near Ringgenberg where Secchi depths were measured before 1954.

predator-prey interactions (Aksnes and Utne, 1997; Beauchamp et al., 1999; Davies-Colley and Smith, 2001). However, enhanced nutrient input due to erosion, untreated wastewater or agricultural runoff leads to higher production and subsequently increased concentrations of particulate and dissolved organic substances in downstream lakes. Thus, lake eutrophication is often associated with reduced water clarity and stronger light attenuation (Goldman, 1988; Sanden and Hakansson, 1996), whereas oligotrophication is usually related to an increase in water clarity (Schanz, 1994; Jeppesen et al., 2005).

Some lakes have experienced significant changes in their riverine particle input (Biggs and DaviesColley, 1990; Davies-Colley et al., 1993; Finger et al., 2006), especially in mountainous regions with high ablation rates (Hinderer, 2001) and glaciated catchments (Bezinge, 1987). For example, extensive damming for hydroelectric power in the European Alps during the last decades has led to significant particle retention (Schleiss and Oehy, 2002; Anselmetti et al., 2007), and alteration of the seasonal particle flux, thereby affecting the physical boundary conditions in downstream lakes (Loizeau and Dominik, 2000; Finger et al., 2006).

Lake Brienz, which is located in the foothills of the Swiss Alps, contains a volume of $5.15 \mathrm{~km}^{3}$, covers a surface area of $30 \mathrm{~km}^{2}$ and is $259 \mathrm{~m}$ deep, provides an excellent example of this phenomenon. About $20 \%$ of the $1134 \mathrm{~km}^{2}$ large alpine watershed is covered by glaciers. Today, $\sim 300 \mathrm{kt} \mathrm{yr}^{-1}$ of inorganic particles are delivered by the two main tributaries, the Aare and
Lütschine Rivers (Fig. 1), leading to a turbid, turquoise appearance of the lake during glacier melting in summer (Finger et al., 2006). During the last 70 years seven hydropower reservoirs with an operable storage volume of $0.197 \mathrm{~km}^{3}$ have been constructed in the headwaters of the Aare. These reservoirs retain $\sim 232 \mathrm{kt} \mathrm{yr}^{-1}$ of coarse particles (Anselmetti et al., 2007) and shift $~ 14 \%$ of the annual Aare discharge from summer to winter, thereby increasing the particle flux during winter by $\sim 5$ times (Finger et al., 2006). In the following we will refer to the period before the construction of the first dam as the pre-dam scenario and the period since the completion of the last dam as the present situation. Beside changes in light attenuation due to the altered particle input, the soluble reactive phosphorous supply to the lake has continuously declined since the 1970s due to the construction of sewage treatment plants (Müller et al., 2007), limiting the biological productivity in Lake Brienz (Finger et al., 2007).

The goal of this paper is to examine the role of upstream hydropower operation and oligotrophication on the light attenuation and reflectance in Lake Brienz by addressing three questions: (1) How is the light attenuation affected by hydropower operation? (2) What are the main causes for the inter-annual and short-term variability of attenuation? and (3) What are the potential causes for the subjective changes in turbidity observed by locals in the last few decades? 


\section{Concepts of light regimes in natural waters}

The simplest method to determine water clarity consists of lowering a Secchi disk into the water and measuring the depth at which it is no longer visible. The Secchi depth is governed by light and beam attenuation and thus is based on the decrease in irradiance with depth in a water body (Tyler, 1968; Preisendorf, 1986; Davies-Colley and Smith, 2001). Conversely, beam attenuation defines the weakening of a light ray sent through a water sample. Two processes are responsible for the attenuation: (1) scattering, mainly by inorganic particles and (2) absorption by pure water, organic tripton (inanimate particulate organic matter), gilvin (dissolved colored organic matter, mainly humic substances) and phytoplankton (Kirk, 1994). In oligotrophic lakes, attenuation due to phytoplankton, organic tripton and gilvin is very low (Kirk, 1994; Krause-Jensen and SandJensen, 1998), and the scattering of light by inorganic particles dominates. The intensity of scattering depends mainly on the mineralogical composition as well as particle size and concentration (Baker and Lavelle, 1984; Spinrad, 1986). Whereas scattering can lead to effective beam attenuation (any scattering of the original light beam is attributed to attenuation), light attenuation is much less affected. Only backward scattering (backscattering) leads directly to attenuation, whereas forward scattering merely prolongs the light path and thereby increases absorption (Kirk, 1985).

The ratio between backscattering and absorption defines the reflectance as the proportion of upward to downward irradiance (Kirk, 1994). High reflectance is associated with a cloudy turquoise appearance of the water, colloquially called turbidity. Scientifically, turbidity denotes the scattering of light at a specific angle (mostly $90^{\circ}$ ) relative to an arbitrary standard; therefore turbidity is a relative quantity (DaviesColley and Smith, 2001). The key factor to resolve with respect to lake productivity is in-situ vertical light attenuation, as it governs the ambient light availability.

\section{Materials and methods}

In order to assess the impact of hydropower operation on the seasonal pattern of light attenuation, we correlated measured attenuations with observed and modeled particle concentrations as well as Secchi depths. These empirical relationships allow us to reconstruct the light attenuation prior to the construction of hydropower dams based on pre-dam Secchi depths and simulated no-dam particle concen- trations (Finger et al., 2006). By quantifying reflectance based on measurements of optical properties as well as the analysis of optically active constituents and published data, we can estimate, semi-quantitatively, the perceived turbidity during the course of oligotrophication in the last 30 years. All measurements and data sets used within this study are summarized in Table 1.

\section{Beam attenuation and optically active constituents}

To determine the beam attenuation, water samples at different depths in Lake Brienz were collected at five occasions between August 2004 and March 2005 at location A (Fig. 1). Spectral beam attenuation was measured in the samples at 400 to $700 \mathrm{~nm}$ wavelengths using a U2000 spectrophotometer (Hitachi, Japan). In order to distinguish between attenuation due to suspended and dissolved substances, spectra were determined in unfiltered and filtered samples, using 11- $\mu \mathrm{m}$ mesh size nylon filter (Milipore, USA) and 0.2$\mu \mathrm{m}$ pore size cellulose acetate membrane filters (Schleicher und Schuell, Germany), consecutively. Based on the measured radiant flux, $\Phi$, in the water sample, beam attenuation coefficients, $\mathrm{c}_{\Phi}(\lambda)$, of the optically active water compounds were determined according to Kirk (1994):

$$
\begin{aligned}
\mathrm{c}_{\Phi}(\lambda) & =2.303 \cdot \log \left[\Phi_{0}(\lambda) / \Phi(\lambda)\right] / r \\
& =\ln \left[\Phi_{0}(\lambda) / \Phi(\lambda)\right] / r
\end{aligned}
$$

where $\Phi$ is measured relative to a nanopure water reference $\left(\Phi_{\mathrm{o}}\right)$ after passing a cell length $\mathrm{r}$ of $0.10 \mathrm{~m}$. Whereas beam attenuation in the unfiltered water samples is due to all optically active compounds, beam attenuation in the filtered water can be attributed to the absorption of gilvin (Kirk, 1994).

All samples were also analyzed for total suspended particles (C), particulate organic carbon (POC) and dissolved organic carbon (DOC). $\mathrm{C}$ was determined gravimetrically on glass microfibre filters $(\mathrm{GF} / \mathrm{F}$, Whatman, UK) (APHA, 1998; Finger et al., 2006). POC was measured by Rellstab et al. (2007), applying combustion at $880^{\circ} \mathrm{C}$ with a Rok $3 / 30$ furnace (Heraeus, Germany) and subsequent IR-detection of the produced $\mathrm{CO}_{2}$. DOC was quantified in the filtered samples after acidification with $1 \%$ of $2 \mathrm{M} \mathrm{HCl}$, combustion and subsequent detection of the generated $\mathrm{CO}_{2}$ in a TOC-5000 (Shimadzu, Japan).

\section{In situ attenuation measurements}

The water and soil protection laboratory of the canton of Bern (GBL) has measured profiles of photosynthetically active radiation (PAR, denoted as $\mathrm{E}_{0} ; \mu \mathrm{E}$ $\mathrm{m}^{-2} \mathrm{~s}^{-1} ; 400<\lambda<700 \mathrm{~nm}$ ) in the lake since 1999 using a spherical underwater LI-193SA sensor (LI-COR Inc, 
Table 1. Overview of measurements and available data

\begin{tabular}{|c|c|c|c|c|c|c|}
\hline Parameter & Symbol & Unit & Period & Sampling & $\mathrm{N}^{(\mathrm{a})}$ & Source \\
\hline \multicolumn{7}{|l|}{ LIGHT MEASUREMENTS } \\
\hline \multirow[t]{3}{*}{ Scalar irradiance PAR } & $\mathrm{E}_{0}$ & 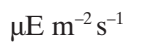 & 1999-2005 & monthly & 84 & GBL, unpublished \\
\hline & & & 1987 & monthly & 13 & Kirchhofer, 1990 \\
\hline & & & 1994 & monthly & 6 & Pfunder, 1994 \\
\hline Downward irradiance & $\mathrm{E}_{\mathrm{d}}(\lambda, \mathrm{z})$ & $\mathrm{W} \mathrm{m}^{-2}$ & $2004-2005$ & Aug - Mar ${ }^{(b)}$ & 5 & Authors \\
\hline Upward radiance & $\mathrm{L}_{\mathrm{u}}(\lambda, \mathrm{z})$ & $\mathrm{W} \mathrm{m} \mathrm{m}^{-2} \mathrm{sr}^{-1}$ & $2004-2005$ & Aug - Mar ${ }^{(b)}$ & 5 & Authors \\
\hline Beam attenuation & $\mathrm{c}_{\theta}(\lambda)$ & $\mathrm{m}^{-1}$ & $2004-2005$ & Aug - Mar ${ }^{(b)}$ & 49 & Authors \\
\hline \multicolumn{7}{|c|}{ OPTICALLY ACTIVE CONSTITUENTS } \\
\hline Particulate matter & $\mathrm{C}$ & $\mathrm{mg} \mathrm{L}^{-1}$ & $2004-2005$ & Aug $-\operatorname{Mar}^{(\mathrm{b})}$ & 49 & Finger et al., 2006 \\
\hline Dissolved organic carbon & DOC & $\mathrm{mg} \mathrm{L}^{-1}$ & $2004-2005$ & Aug $-\operatorname{Mar}^{(\mathrm{b})}$ & 30 & Authors \\
\hline Particulate organic carbon & POC & $\mathrm{mg} \mathrm{L}^{-1}$ & $2004-2005$ & Aug $-\operatorname{Mar}^{(b)}$ & 49 & Rellstab et al., 2007 \\
\hline \multicolumn{7}{|l|}{ SECCHI DEPTH } \\
\hline \multirow[t]{6}{*}{ Secchi depth } & $\mathrm{z}_{\mathrm{SD}}$ & $\mathrm{m}$ & $1921-1923$ & biweekly & 37 & Flück, $1926^{\text {(c) }}$ \\
\hline & & & $1945-1949$ & weekly & 140 & Hofer, $1952^{\text {(c) }}$ \\
\hline & & & $1953-1954$ & bimonthly & 9 & Nydegger, 1957 \\
\hline & & & 1985-1989 & monthly & 33 & Kirchhofer, 1990 \\
\hline & & & $1993-2005$ & biweekly & 2964 & GBL, unpublished ${ }^{\text {(d) }}$ \\
\hline & & & $1999-2005$ & monthly & 71 & GBL, unpublished $^{(\mathrm{e})}$ \\
\hline
\end{tabular}

(a) $\mathrm{N}$ denotes the number of profiles or samples.

(b) 25 August 2004, 11 October 2004, 9 November 2004, 21 December 2004, 22 March 2005.

(c) Measurements performed in the western part of the lake (Fig. 1).

(d) Measurements performed by a fisherman on behalf of GBL.

(e) Data was used for correlation with attenuation and particle concentration, determined simultaneously.

USA) and a corresponding LI-190SA radiometer above the surface. Additional PAR measurements are available from previous studies (Kirchhofer, 1990; Pfunder, 1994) (Table 1). Underwater $\mathrm{E}_{0}$ was corrected for short-term variations of incoming light (due to clouds) by multiplying it with the quotient of the simultaneously measured irradiance above the surface and to the reference surface irradiance determined at the beginning of the measurement. Attenuation coefficient $\mathrm{K}_{0}$ was determined by fitting an exponential function to the corrected $\mathrm{E}_{0}$ profile from the surface $\left(\mathrm{z}_{0}\right)$ to the euphotic depth $\mathrm{z}_{\mathrm{eu}}$.

$$
E_{0}(z)=E_{0}\left(z_{0}\right) \cdot e^{-K_{0} \cdot z} \quad\left[\mu \mathrm{E} \mathrm{m}^{-2} \mathrm{~s}^{-1}\right]
$$

where $\mathrm{z}_{\mathrm{eu}}$ denotes the depth in a homogenous water column where quantum fluxes have decreased to $1 \%$ of the subsurface value. It can also be expressed as a function of $\mathrm{K}_{0}$ :

$z_{\text {eu }}=\ln (100) / K_{0}=4.61 / K_{0}$

\section{Secchi recordings}

The Secchi depth $z_{\mathrm{SD}}$ has been systematically recorded about four times per week since 1993 by a local resident, whereas prior to $1993 \mathrm{z}_{\mathrm{SD}}$ was recorded on a biweekly to monthly basis (Flück, 1926; Hofer, 1952; Nydegger, 1957; Kirchhofer, 1990) (Table 1). Before 1954, Secchi depths were measured in the western part of the lake ( $~ 500 \mathrm{~m}$ off shore; B in Fig. 1) due to lack of motorized transportation. Although this location might be more affected by particles from the Lütschine, Flück (1926) demonstrated empirically that this sampling site was representative for the open water of the lake in summer.

\section{Reflectance measurements}

To estimate reflectance in Lake Brienz, in situ downward irradiance $\mathrm{E}_{\mathrm{d}}(\lambda, \mathrm{z})\left(\mathrm{W} \mathrm{m}^{-2} ; 180^{\circ}\right.$ opening angle $)$ and upward radiance $\mathrm{L}_{\mathrm{u}}(\lambda, \mathrm{z})\left(\mathrm{W} \mathrm{m}^{-2} \mathrm{sr}^{-1} ; 15^{\circ}\right.$ opening angle) were measured from 1 to $20 \mathrm{~m}$ depth at each sampling date (August 2004 to March 2005; Table 1). This was achieved using two GER 1500 radiometers (Geophysical and Environmental Research, USA) that were assembled into one dual-radiometer instrument by the Remote Sensing Laboratory of the University of Zürich (Keller, 2001), which enabled simultaneous measurements of in situ $\mathrm{E}_{\mathrm{d}}(\lambda, \mathrm{z})$ and $\mathrm{L}_{\mathrm{u}}$ $(\lambda, z)$. Spectral irradiance reflectance $R(\lambda, z)$ is defined according to Kirk (1994) by

$R(\lambda, z)=\frac{E_{u}(\lambda, z)}{E_{d}(\lambda, z)}=\frac{Q \cdot L_{u}(\lambda, z)}{E_{d}(\lambda, z)}$

where Q (sr) denotes an experimentally defined factor to convert upward radiance to upward irradiance $\mathrm{E}_{\mathrm{u}}$ $\left(\mathrm{W} \mathrm{m}^{-2}\right)$. Q was estimated experimentally by flipping the dual-radiometer upside down to measure $\mathrm{E}_{\mathrm{u}}(\lambda, \mathrm{z})$ 
Table 2. Parameterization of reflectance

\begin{tabular}{|c|c|c|c|c|c|c|}
\hline & Wavelength $\lambda_{0}(\mathrm{~nm})$ & Value & Unit & Equation & Range & References \\
\hline $\begin{array}{l}\mathrm{a}_{\mathrm{p}} *\left(\lambda_{0}\right)^{(\mathrm{a})} \\
\mathrm{S}_{\mathrm{p}}\end{array}$ & 450 & $\begin{array}{l}0.02 \\
0.02\end{array}$ & $\begin{array}{l}\mathrm{m}^{2} \mathrm{~g}^{-1} \\
\mathrm{~nm}^{-1}\end{array}$ & $\begin{array}{l}(7) \\
(7)\end{array}$ & $\begin{array}{l}0.01-0.067 \\
0.005-0.021\end{array}$ & $\begin{array}{l}\text { (Babin et al., 2003; Doxaran et al., 2006) } \\
\text { (Doxaran et al., 2006) }\end{array}$ \\
\hline $\begin{array}{l}\mathrm{a}_{\mathrm{g}} *(\lambda)^{(\mathrm{a})} \\
\mathrm{S}_{\mathrm{g}}\end{array}$ & 440 & $\begin{array}{l}0.048 \\
0.015\end{array}$ & $\begin{array}{l}\mathrm{m}^{2} \mathrm{~g}^{-1} \\
\mathrm{~nm}^{-1}\end{array}$ & $\begin{array}{l}(9) \\
(9)\end{array}$ & $-\overline{-} 01-0.02$ & $\begin{array}{l}\text { (Keller, 2001) } \\
\text { (Kirk, 1994) }\end{array}$ \\
\hline $\begin{array}{l}\mathrm{b}_{\mathrm{p}} *(\mathrm{a}) \\
\mathrm{T}_{\mathrm{p}}\end{array}$ & 550 & 0.58 & $\mathrm{~m}^{2} \mathrm{~g}^{-1}$ & (11) & $\begin{array}{l}0.3-0.9 \\
0-1\end{array}$ & $\begin{array}{l}\text { (Tassan and Ferrari, 1995; Wozniak and Stramski, 2004; } \\
\text { Doxaran et al., 2006) } \\
\text { (Doxaran et al., 2006) }\end{array}$ \\
\hline $\begin{array}{l}\mathrm{b}_{\text {Chla }} * \text { (a) } \\
\mathrm{T}_{\text {Chla }}\end{array}$ & 550 & $\begin{array}{l}0.1 \\
0.8\end{array}$ & $\mathrm{~m}^{2} \mathrm{mg}^{-1}$ & $\begin{array}{l}(12) \\
(12)\end{array}$ & $\begin{array}{l}0.044-0.139 \\
0-1\end{array}$ & $\begin{array}{l}\text { (Kirk, 1994) } \\
\text { (Frauendorf, 2002) }\end{array}$ \\
\hline
\end{tabular}

(a) The numerical values of the specific absorption and scattering coefficients $a^{*}$ and $b^{*}$ at wavelength $\lambda_{\mathrm{o}}$ are indicated for particles (p), gilvin (g) and Chla with the corresponding exponents $\mathrm{S}$ and $\mathrm{T}$. The typical ranges are documented with literature references.

and dividing $\mathrm{E}_{\mathrm{u}}(\lambda, \mathrm{z})$ by $\mathrm{L}_{\mathrm{u}}(\lambda, \mathrm{z})$. For wavelengths of 450,550 and $650 \mathrm{~nm}, \mathrm{Q} \approx 2.0 \mathrm{sr}$ was found in March 2005. We assume constant $\mathrm{Q}$ for all five observations, as $\mathrm{R}$ is in the same range for all five instances (Jaun, 2005).

\section{Parameterization of reflectance for past conditions}

Human perception of lake conditions depends on the intensity and spectral distribution of the reflectance. To assess the perceived increase in turbidity, reflectance (i.e., equation 4) was parameterized for summer conditions using present levels of optically active compounds and then compared to the hypothetical scenario of a 4-fold increase in productivity, expected during the late 1970s. For this purpose, reflectance was calculated from the total backscattering coefficient $b_{b}$ $\left(\mathrm{m}^{-1}\right)$ and the total absorption coefficient a $\left(\mathrm{m}^{-1}\right)$ (Pierson and Strömbeck, 2001; Frauendorf, 2002; Wozniak and Stramski, 2004; Kallio, 2006):

$\mathrm{R}(\lambda)=\Omega \cdot \frac{\mathrm{b}_{\mathrm{b}}(\lambda)}{\mathrm{b}_{\mathrm{b}}(\lambda)+\mathrm{a}(\lambda)}$

where $\Omega$ denotes a dimensionless factor dependent on the angle of the incoming sunlight. As we consider relative changes of $\mathrm{R}$, the value of $\Omega$ needs not to be exact and $\Omega=0.35$ was chosen as a typical clear sky value (Morel and Prieur, 1977; Kirk, 1994; Frauendorf, 2002). The total absorption coefficient a $(\lambda)$ is the sum of absorption by the different optically active compounds:

$\mathrm{a}(\lambda)=\mathrm{a}_{\mathrm{w}}(\lambda)+\mathrm{a}_{\mathrm{p}}(\lambda)+\mathrm{a}_{\text {Chla }}(\lambda)+\mathrm{a}_{\mathrm{g}}(\lambda) \quad\left[\mathrm{m}^{-1}\right]$

where the subscripts w, p, Chla and g denote pure water, particles, chlorophyll a and gilvin (represented throughout this study by DOC), respectively. The spectral absorption coefficient of water is taken from Pope and Fry (1997). The dependency of absorption by particulate or dissolved matter on the concentra- tion of the specific compounds (C, Chla, DOC) was determined by means of concentration-normalized absorption coefficients $\mathrm{a}^{*}$ taken from various studies as follows:

$\mathrm{a}_{\mathrm{p}}(\lambda)=a_{p}^{*}\left(\lambda_{0}\right) \cdot[C] \cdot \exp ^{-S p\left(\lambda_{0}-\lambda\right)} \quad\left[\mathrm{m}^{-1}\right]$

$\mathrm{a}_{\text {Chla }}(\lambda)=\mathrm{A}(\lambda) \cdot[\mathrm{Chla}]^{(1-\mathrm{B}(\lambda)}$

$\left[\mathrm{m}^{-1}\right]$

$\mathrm{a}_{\mathrm{g}}(\lambda)=a_{g}^{*}\left(\lambda_{0}\right) \cdot[D O C] \cdot \exp ^{-S g\left(\lambda_{0}-\lambda\right)} \quad\left[\mathrm{m}^{-1}\right]$

The values of a* at reference wavelength $\lambda_{\mathrm{o}}$ and of the exponent $S$ in equations (7) and (9) are specified in Table 2. Equation (8) and the parameters A and B have been derived from numerous observations by Bricaud et al. (1995). B is a dimensionless number, A and Chla have units of $\mathrm{m}^{-1}$ and $\mathrm{mg} \mathrm{m}^{-3}$, respectively.

Similar to equation (6), the scattering coefficient $b$ is defined as the sum of scattering by pure water, particles and Chla, whereas scattering by gilvin is negligible (Bricaud et al., 1981):

$\mathrm{b}(\lambda)=\mathrm{b}_{\mathrm{w}}(\lambda)+\mathrm{b}_{\mathrm{p}}(\lambda)+\mathrm{b}_{\text {Chla }}(\lambda)$

$\left[\mathrm{m}^{-1}\right]$

The backscattering coefficient of water $b_{b, w}$ is half of the scattering coefficient $b_{w}$, since water molecules scatter light isotropically (Morel, 1974). For the spectral backscattering of particles and Chla we used the following parameterizations:

$$
\begin{array}{r}
\mathrm{b}_{\mathrm{b}, \mathrm{p}}(\lambda)=0.033 \cdot\left[\mathrm{b}_{\mathrm{p}}^{*}\left(\lambda_{0}\right) \cdot[\mathrm{C}] \cdot\left(\lambda / \lambda_{0}\right)^{-\mathrm{T}_{\mathrm{p}}}\right] \quad\left[\mathrm{m}^{-1}\right] \\
\mathrm{b}_{\mathrm{b}, \text { Chla }}(\lambda)=0.004 \cdot\left[\mathrm{b}_{\text {Chla }}^{*}\left(\lambda_{0}\right) \cdot[\text { Chla }] \cdot\left(\lambda / \lambda_{0}\right)^{-\mathrm{T}_{\text {cha }}}\right] \\
{\left[\mathrm{m}^{-1}\right]}
\end{array}
$$

For particles, the ratio of backscattering to scattering is typically 0.019 (Kirk, 1994) with values up to 0.07 to 0.08 (Whitlock et al., 1981; Tassan and Ferrari, 1995), 
whereas for phytoplankton this ratio is only $\sim 0.001$ to 0.004 (Frauendorf, 2002). The two factors $(0.033$ and $0.004)$ were chosen to match the measured $R(\lambda)$ (Equation 5). A wide range of values have been reported for the specific scattering coefficients $b *$ and the exponents $\mathrm{T}$ (Table 2). Whereas $\mathrm{T}_{\mathrm{p}}$ and $\mathrm{b}_{\mathrm{p}}^{*}$ were estimated by Jaun (2005), $b_{\text {Chla }}^{*}$ was chosen according to Kirk (1994), and $\mathrm{T}_{\text {Chla }}$ was taken from (Wozniak and Stramski, 2004).

\section{Reconstruction of attenuation by Secchi depth and particles}

Based on our data from 1999 to 2004 (Table 1), $\mathrm{K}_{0}$ relates to the inverse of the Secchi depth, $\mathrm{z}_{\mathrm{SD}}$, as follows:

$\mathrm{K}_{0}=\beta_{1}+\alpha_{1} \cdot \mathrm{z}_{\mathrm{SD}}^{-1}$

$\left[\mathrm{m}^{-1}\right]$

Using this relation, $\mathrm{K}_{0}$ can be reconstructed with Secchi depths for periods previous to our sampling and compared to the radiometric measurements performed by Kirchhofer (1990) and Pfunder (1994). Furthermore, $\mathrm{K}_{0}$ was correlated with simultaneously determined particle concentration $\mathrm{C}$ (Finger et al., 2006) according to the following relation:

$\mathrm{K}_{0}=\beta_{2}+\alpha_{2} \cdot \mathrm{C}$

$\left[\mathrm{m}^{-1}\right]$

For $\mathrm{C}$ we used average particle concentrations from the euphotic zone $\overline{\mathrm{C}}\left(\mathrm{z}_{\mathrm{eu}}\right)$ and from the top $50 \mathrm{~m}$ water column $\bar{C}\left(z_{50}\right)$. Since there are no $K_{0}$ and only scarce $\mathrm{Z}_{\mathrm{SD}}$ recordings available for the first half of the last century, $\overline{\mathrm{C}}\left(\mathrm{z}_{50}\right)$ was simulated from 1995 to 2004 using water discharge, particle loads and intrusion dynamics according to Finger et al. (2006). The same model was also used to reconstruct $\overline{\mathrm{C}}\left(\mathrm{z}_{50}\right)$ for the hypothetical scenario without hydropower dams in the headwaters of the Aare (Finger et al., 2006).

This procedure provides two independent estimates on how attenuation in Lake Brienz has changed by upstream damming: firstly via particle concentrations (Finger et al., 2006) and secondly via pre-dam Secchi depth records (Flück, 1926).

\section{Results}

\section{Present light regime in Lake Brienz}

The inorganic particle loads (Finger et al., 2006) in the two major inflows $\left(\sim 300 \mathrm{kt} \mathrm{yr}^{-1}\right)$ dominate the light attenuation in Lake Brienz. Consequently, particle dynamics in the top $50 \mathrm{~m}$ of Lake Brienz are governed by snow/glacial melting and heavy precipitation events during summer (leading to high particle loads) and low discharge, since most precipitation occurs as snow in winter (implying minimal particle loads; Finger et al., 2006). During summer the vertically-averaged concentrations $\overline{\mathrm{C}}\left(\mathrm{z}_{50}\right)$ in the uppermost $50 \mathrm{~m}$ of the water column reach $>5 \mathrm{mg} \mathrm{L}^{-1}$, whereas in winter $\overline{\mathrm{C}}\left(\mathrm{z}_{50}\right)$ drop back to 1 to $2 \mathrm{mg} \mathrm{L}^{-1}$ throughout the entire volume (Fig. 2). The Secchi depth, light attenuation $K_{0}$ and euphotic depth $z_{\mathrm{eu}}$ determined from measured PAR profiles (equation 3 ) follow the temporal dynamics of $\mathrm{C}$ (Fig. 2a). While during summer, when $\mathrm{C}$ reaches a maximum, light is limited to the top $10 \mathrm{~m}$ and $\mathrm{z}_{\mathrm{eu}}$ in winter can reach down to $25 \mathrm{~m}$ depth.

The low concentrations of POC $\left(0.05\right.$ to $0.25 \mathrm{mg} \mathrm{L}^{-1}$; Rellstab et al., 2007) and Chla (0.1 to $2 \mu \mathrm{g} \mathrm{L}^{-1}$; Finger et al., 2007) reinforce the assumption that attenuation is mainly due to scattering caused by small inorganic particles. In fact, calculations of the scattering contributions reveal that particles with diameters smaller than $4 \mu \mathrm{m}$ account for $\sim 70$ to $80 \%$ of the scattering (Jaun, 2005; Swift et al., 2006). The beam attenuation of gilvin $\left(\mathrm{a}_{\mathrm{g}}\right)$, measured in filtered water samples, was mostly below the sensitivity limit of the spectrophotometer of $0.1 \mathrm{~m}^{-1}$. This is reasonable since typical concentrations of dissolved organic carbon (DOC) are $0.5 \mathrm{mg} \mathrm{L}^{-1}$. Using the specific DOC attenuation values of $0.0539 \mathrm{~m}^{2} \mathrm{~g}^{-1}$ for 400 to $700 \mathrm{~nm}$ (Jaquet et al., 1994) and $\sim 0.015 \mathrm{~m}^{2} \mathrm{mg}^{-1}$ for Chla (Morel and Prieur, 1977), it was estimated that Chla and gilvin account for only $\sim 5 \%$ of the beam attenuation.

\section{Temporal development of Secchi depth during the $\mathbf{2 0}^{\text {th }}$ century}

Secchi depth $\mathrm{z}_{\mathrm{SD}}$ recordings of various temporal resolutions exist since 1921 (Table 1). Concerning the role of the upstream hydropower development, the following periods of $z_{\mathrm{SD}}$ recordings (Fig. 3) are of interest: (i) pre-dam: 1921 to 1923 (natural flow), (ii) inter-dam: 1945 to 1949 (completion of half of the dams) and (iii) present situation (completion and operation of all dams). We separate the present period (iii) into: 1985 to 1989 (high productivity) and 1993 to 2005 (oligotrophication; status quo scenario). The recordings in 1953 and 1954 (Nydegger, 1957) consist of only nine data points and should be interpreted with caution (Siegenthaler, 2003).

Present $z_{\mathrm{SD}}$ follow the same seasonal structure as $\overline{\mathrm{C}}\left(\mathrm{z}_{50}\right)$ (Fig. 2): In summer, $\mathrm{z}_{\mathrm{SD}}$ reaches a minimum of 2 to $3 \mathrm{~m}$ and a maximum of 5 to $7 \mathrm{~m}$ in winter. Spring is characterized by strong fluctuations (Fig. 3).

Pre-dam $z_{\mathrm{SD}}$ recordings (Table 1) available in 1921 / 1922 (bi-weekly) and 1923 (one $\mathrm{z}_{\mathrm{SD}}$ recording only) show a strong variation in spring with $\mathrm{z}_{\mathrm{SD}} \sim 8$ to $9 \mathrm{~m}$ and 5 to $6 \mathrm{~m}$, respectively (Fig. 3). The shallowest pre-dam $\mathrm{z}_{\mathrm{SD}}$ was observed in summer $1923(0.45 \mathrm{~m})$. In summer, Secchi depths were deeper during the inter-dam period 
a)
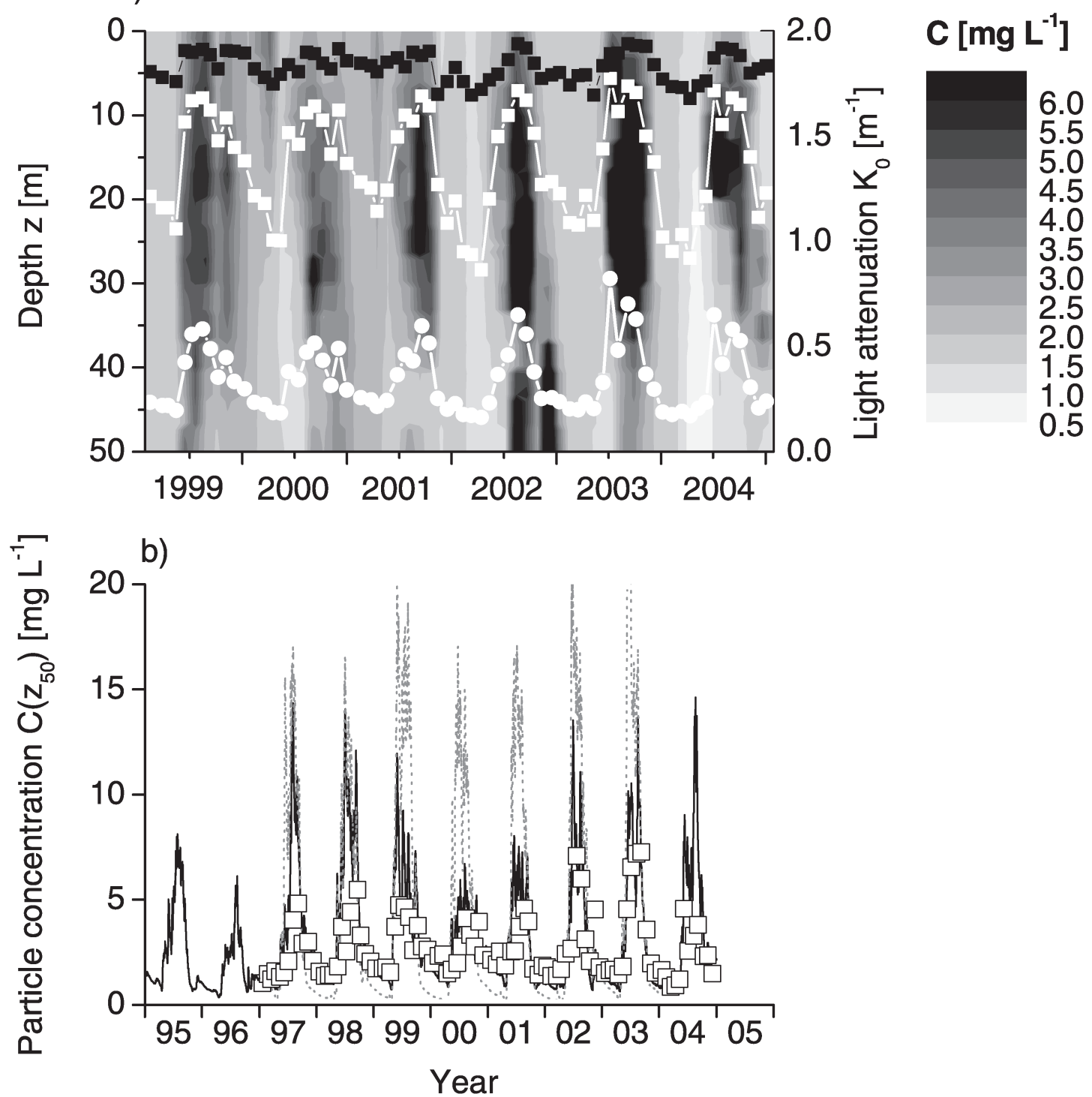

Figure 2. Status quo particle concentrations in the top $50 \mathrm{~m}$ water column of Lake Brienz from 1995 to 2005 as (a) contour plot and (b) average in the top $50 \mathrm{~m}$. (a) present Secchi depth (black squares), euphotic depth (white squares) and light attenuation (white circles; right scale). (b) illustrates average particle concentrations in the top $50 \mathrm{~m}$ determined in water samples (open squares), simulated (black line) for status quo scenario and simulated for no-dam scenario (dotted grey line). The figure was adopted from Finger et al. (2006).

of the 1940s and were deepest under present conditions, although the inter-annual fluctuations were large.

Exceptionally clear water was observed from 1995 to 1997: $\mathrm{z}_{\mathrm{SD}}$ reached an extraordinary maximum of $16.9 \mathrm{~m}$ in fall 1995, when no rain fell for more than four weeks (data: MeteoSwiss). Conversely, especially low clarity was measured after the flood in August 2005 $\left(\mathrm{z}_{\mathrm{SD}}=0.7 \mathrm{~m}\right)$.

\section{Correlation of attenuation with Secchi depth and particles}

As we lack attenuation measurements from the past, we use the Secchi depth $\mathrm{z}_{\mathrm{SD}}$ and particle concentra- tions $\overline{\mathrm{C}}\left(\mathrm{z}_{50}\right)$ as surrogates for reconstructing light attenuation prior to 1999. The variables are moderately to highly correlated, with $\mathrm{R}^{2}$ between 0.55 and 0.85 (Fig. 4). The regressions were calculated separately for summer (May to September) and winter (October to April) for two reasons: (1) In summer there is a significant vertical particle gradient in the top $50 \mathrm{~m}$ (Fig. 2), which is not present during times of deep convective mixing in winter. Therefore $K_{0}$ and $\overline{\mathrm{C}}\left(\mathrm{z}_{50}\right)$ do not pertain to the same layers. (2) During winter (low input), the particles are smaller on average (Finger et al., 2006), leading to different $\mathrm{K}_{0}$ per unit mass. 


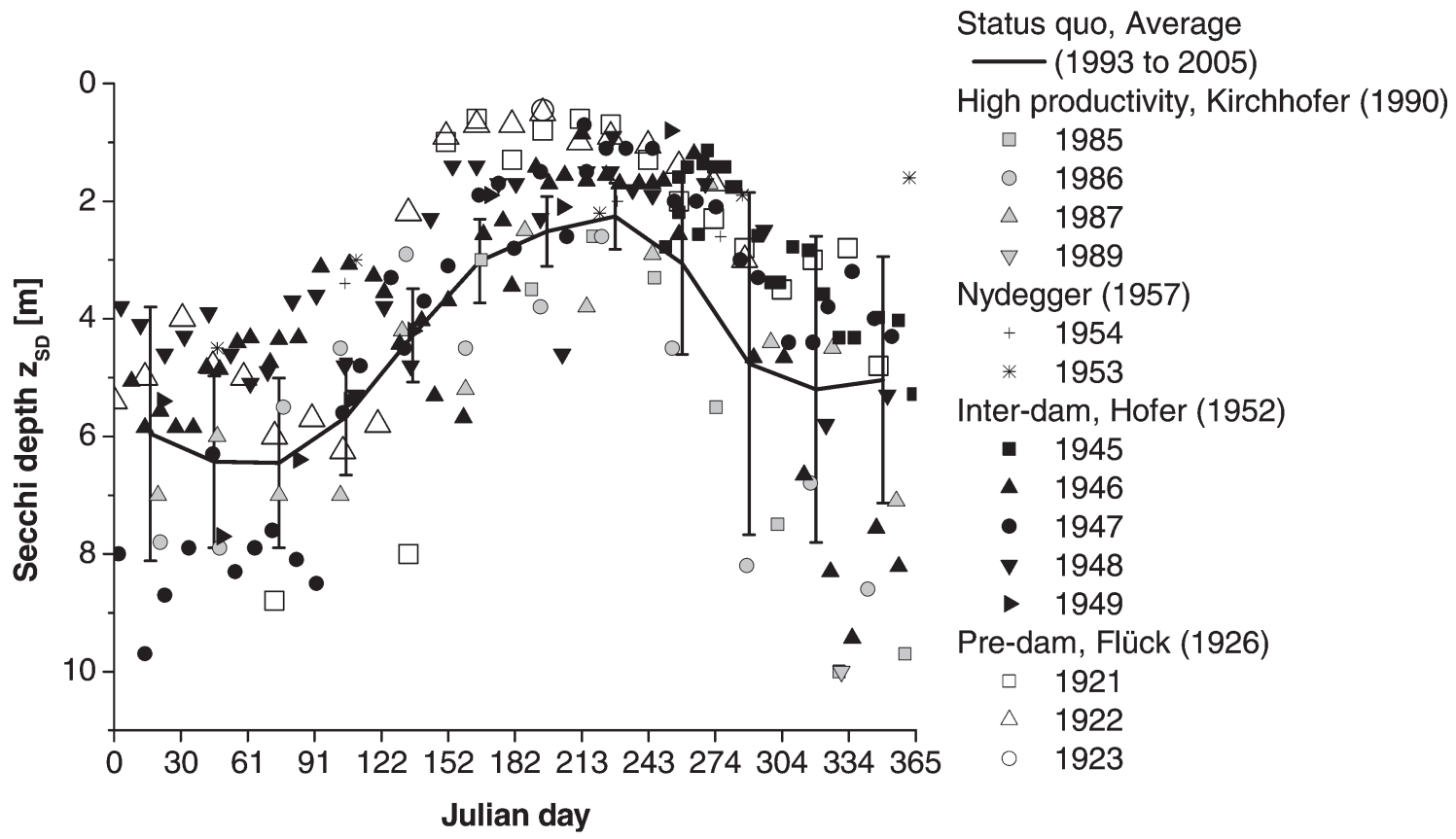

Figure 3. Secchi depth in Lake Brienz from 1921 to 2005. Recordings are grouped according to different episodes of hydropower exploitation: pre-dam (open symbols), inter-dam (black symbols) and present situation (since the late 1980s: grey symbols). For orientation the average and standard deviations for the period 1993 to 2005 is illustrated as a solid line.

As $\mathrm{K}_{0}$ is estimated within the euphotic zone, the correlation of $\mathrm{K}_{0}$ with particles is stronger for $\overline{\mathrm{C}}\left(\mathrm{z}_{\mathrm{eu}}\right)$ than for $\overline{\mathrm{C}}\left(\mathrm{z}_{50}\right)$ (Fig. 4). However, due to the complexity of the processes involved and the vertical resolution of the simulated particle distributions (Finger et al., 2006), we chose $\bar{C}\left(z_{50}\right)$ as the proxy for the concentrations in the past. From 1999 to 2004, the two independent $\mathrm{K}_{0}$ estimates can be compared to the status quo scenario (Fig. 5). Predictions based on Secchi depth and simulated particle concentrations have a higher temporal resolution ( 1 day and 0.1 day, respectively), also depicting short-term turbidity events.

This reconstruction allows a comparison of the attenuations of the status quo scenario with scenarios without dams based on no-dam $\overline{\mathrm{C}}\left(\mathrm{z}_{50}\right)$ and on pre-dam Secchi depths $z_{\mathrm{SD}}$ (Fig. 6). Although the inter-annual and short-term variations of attenuation are very large (Fig. 5), the overall outcome is clear; attenuation without dams would be about twice compared to present in summer, whereas in winter $\mathrm{K}_{0}$ would be about half of the status quo level. Although the uncertainty of the reconstructed no-dam $\mathrm{K}_{0}$ is high, both particles and Secchi depths indicate an enhanced attenuation in summer compared to the status quo conditions.

\section{Natural variability of attenuation}

To evaluate the reconstructed attenuation, we compared $\mathrm{K}_{0}$ estimates based on the Secchi depth and simulated particle concentrations with $\mathrm{K}_{0}$ determined from measured PAR profiles. Independent radiometric measurements in 1987 and 1994 by Kirchhofer (1990) and Pfunder (1994) show convincing agreement with $\mathrm{K}_{0}$ derived from $\mathrm{Z}_{\mathrm{SD}}$ (Fig. 5). Exceptions are the data from 7 July 1987, when heavy rainfall occurred immediately before sampling (Kirchhofer, 1990).

The $\mathrm{z}_{\mathrm{SD}}$-based attenuation in 1985 and 1986 was clearly below the 1987 estimates. This is consistent with the observation that particle inputs were well below average in 1985 and well above average in 1987. Extremely low attenuation was observed from fall 1995 to spring 1997. As outlined in the discussion, this variability can be explained by discharge and load patterns in the two river inflows.

In winter and spring 1999 exceptional snow- and rainfall caused unusually high discharge in May 1999 along with particle loads 4-fold higher than average (Finger et al., 2006). During this period, Secchi depths and attenuation showed decreased and increased values, respectively.

During the heat wave in summer 2003 enhanced glacial melting increased the particle load of the Lütschine to $\sim 35 \%$ above average, whereas it was reduced to half in the Aare because there was almost no precipitation, while glacial particles were largely retained in the upstream reservoirs (Finger et al., 2006). Since both rivers intruded mostly into the surface layer during this period, $\mathrm{K}_{0}$ was higher than 
a)

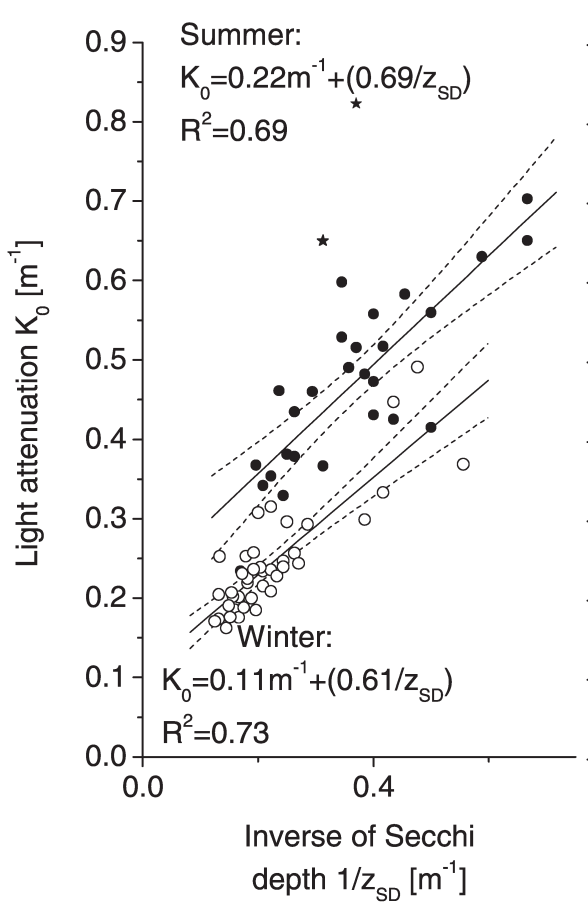

b)

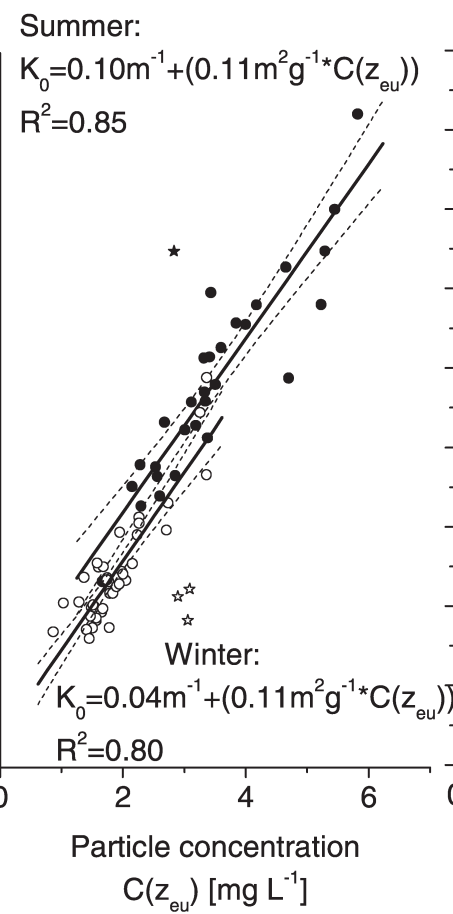

c)

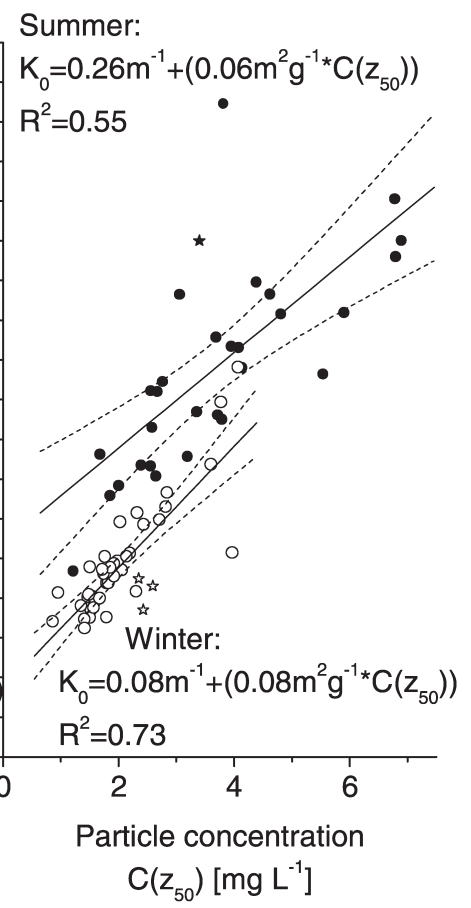

Figure 4. Correlation of light attenuation $\mathrm{K}_{0}$ with a) Secchi depth, b) mean particle concentration in the euphotic layer and c) mean particle concentrations in the top $50 \mathrm{~m}$. Black circles indicate data points during summer (May to September) and open circles during winter (October to April) of monthly measurements from 1999 to $2004\left(\mathrm{~N}_{\mathrm{W}}=39, \mathrm{~N}_{\mathrm{S}}=30 ; \mathrm{p}<0.001\right)$. The solid line represents the respective linear regressions, dotted line illustrates the upper and lower $95 \%$ confidence limits and star symbols represent outliers not considered for regression (criteria for outliers were determined in b).

usual. Extreme conditions occurred in August 2005 as a result of flooding. Exceptional particle input increased $\mathrm{K}_{0}$ to 0.9 to $1.2 \mathrm{~m}^{-1}$.

We conclude that inter-annual and short-term fluctuations due to exceptional weather conditions can reach as much as a factor of 2 . The fluctuations in Secchi depth and attenuation are mainly explained by variations in natural discharge and not so much by hydropower operations, since there were no significant inter-annual changes of the ratio of reservoir discharge per total discharge (KWO, unpublished data).

\section{Changes in reflectance due to oligotrophication}

Local residents claim that turbidity has increased during the last decades. Reflectance, the ratio of backscattering per attenuation (back scattering plus absorption; Equation 5), quantifies best the visual perception of turbidity in natural waters. Measurements revealed that the reflectance in the upper $8 \mathrm{~m}$ of Lake Brienz varied from 12 to $24 \%$ in the spectral range of 500 to $550 \mathrm{~nm}$ (Fig. 7). At longer wavelengths reflectance is low because of high absorption by water, whereas the increased absorption by organic compounds towards shorter wavelengths also causes lower reflectance.
During winter and spring (profiles from December and March), the reflectance is highest, since there are only low levels of light-absorbing organic compounds but backscattering is pronounced due to the small particles (Finger et al., 2006). In summer (profiles from August and October), reflectance is lower than in winter since absorption at enhanced levels of organic matter increases more than the particle-induced backscattering. This effect was strongest in November 2004, when the organic fraction of particulate matter was highest and consequently reflectance was at a minimum. The vertical variation of reflectance in the upper $8 \mathrm{~m}$ water column is $\sim 10 \%$ of its value, with the largest fluctuations in August ( $25 \%)$ and October $(40 \%)$ due to vertical particle gradients (Fig. 2).

Lake Brienz has been subjected to a continuous decline of bio-available phosphorous input from $\sim 33 \mathrm{t}$ $\mathrm{yr}^{-1}$ in the late 1970 s to $\sim 8 \mathrm{t} \mathrm{yr}^{-1}$ in recent years (Müller et al., 2007). As primary production in Lake Brienz is strongly phosphorous limited (Finger et al., 2007), it can be assumed that optically active organic substances have been decreasing proportionally to the phosphorous input. Using equation (5) the reflectance is calculated for a status quo summer situation, using concentrations of optically active constituents as measured on 25 August 2004 (Table 3) and for 4-fold 


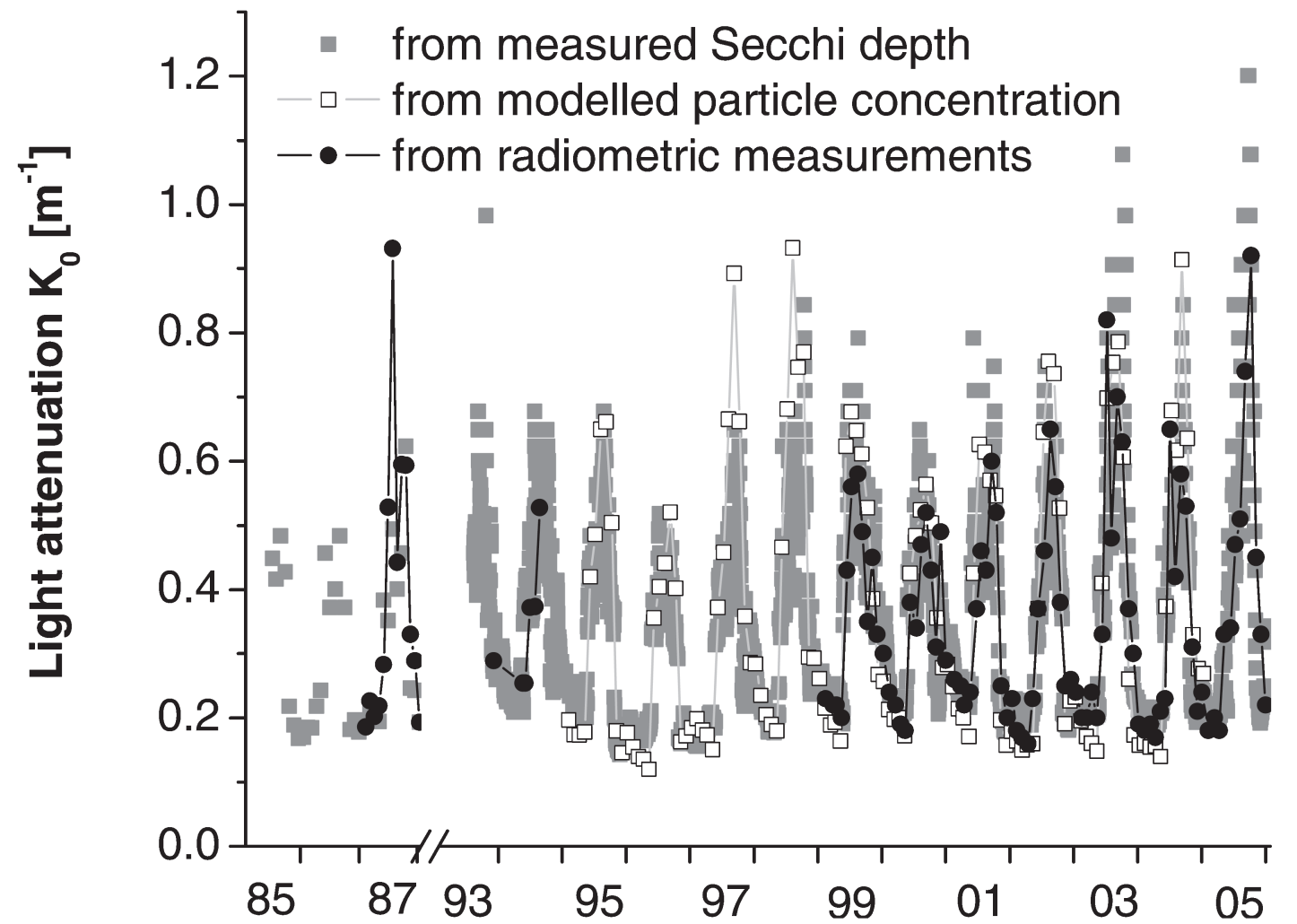

Figure 5. Light attenuation $\mathrm{K}_{0}$ from 1985 to 2005 from radiometric profiles (black circles: determined with equation 2), from continuous $\mathrm{z}_{\mathrm{SD}}$ recordings (grey squares: predicted with correlations (Winter and Summer) from Fig. 4) and from modeled C( $\left.\mathrm{z}_{50}\right)$ (white squares: predicted with correlations from Fig. 4).

higher concentrations of optically active organic substances, expected in the late 1970s (Müller et al., 2007). The most pronounced differences due to oligotrophication are expected during the productive season. Higher productivity in Lake Brienz is expected to have two effects: (1) enhanced concentrations of Chla and DOC and (2) increased sedimentation of inorganic particles due to biological and chemical coagulation (Gliwicz, 1986; Chanudet and Filella, 2007).

In order to assess the effects of oligotrophication on the perceived turbidity, we predicted reflectance for a 4-fold higher concentration of organic compounds using the parameterization of equations (5) to (12). The reflectance at the wavelength of $\sim 550 \mathrm{~nm}$, which is the maximum sensitivity of human eyes (Kirk, 1985 ), yields $\sim 16 \%$ for the status quo scenario in summer (Fig. 8). A typical variation in particle concentration of $\pm 1 \mathrm{mg} \mathrm{L}^{-1}$ in summer causes a range of $\sim 14$ to $18 \%$ reflectance under present levels of optically active compounds. For a hypothetical summer during a productive decade (4-fold levels of Chla and DOC), one could expect a reflectance of 11 to $14 \%$. Assuming that the particle concentration and characteristics were the same in the past, the calculations indicate an increase in reflectance by $\sim 20$ to
Table 3. Typical concentration values for particles, Chla and DOC in summer

\begin{tabular}{lllll}
\hline & Unit & Status quo $^{(\text {a) }}$ & Productive Period $^{(\text {b) }}$ & Equation \\
\hline Particles, & $\mathrm{mg} \mathrm{L}^{-1}$ & $4 \pm 1$ & $4 \pm 1$ & $(7),(11)$ \\
Chla & $\mu \mathrm{g} \mathrm{L}^{-1}$ & 2 & 8 & $(8),(12)$ \\
DOC & $\mathrm{mg} \mathrm{L}^{-1}$ & 0.5 & 2 & (9) \\
\hline
\end{tabular}

(a) For the status quo mean concentrations from 25 August 2004 are listed

(b) For the productive period (late 1970s), according to equation (6), a 4-fold increase of Chla and DOC is assumed.

$25 \%$ as a result of oligotrophication. In addition, assuming a realistic increase in particle concentration of $1 \mathrm{mg} \mathrm{L}^{-1}$ due to weakened bio-enhanced sedimentation (Chanudet and Filella, 2007), reflectance could have increased by 40 to $45 \%$ during the last 25 years. Moreover, in the last few years the summer maxima of fine particles were enhanced due to strong glacial melting (Finger et al., 2006), also causing enhanced backscattering and reflectance in Lake Brienz. 


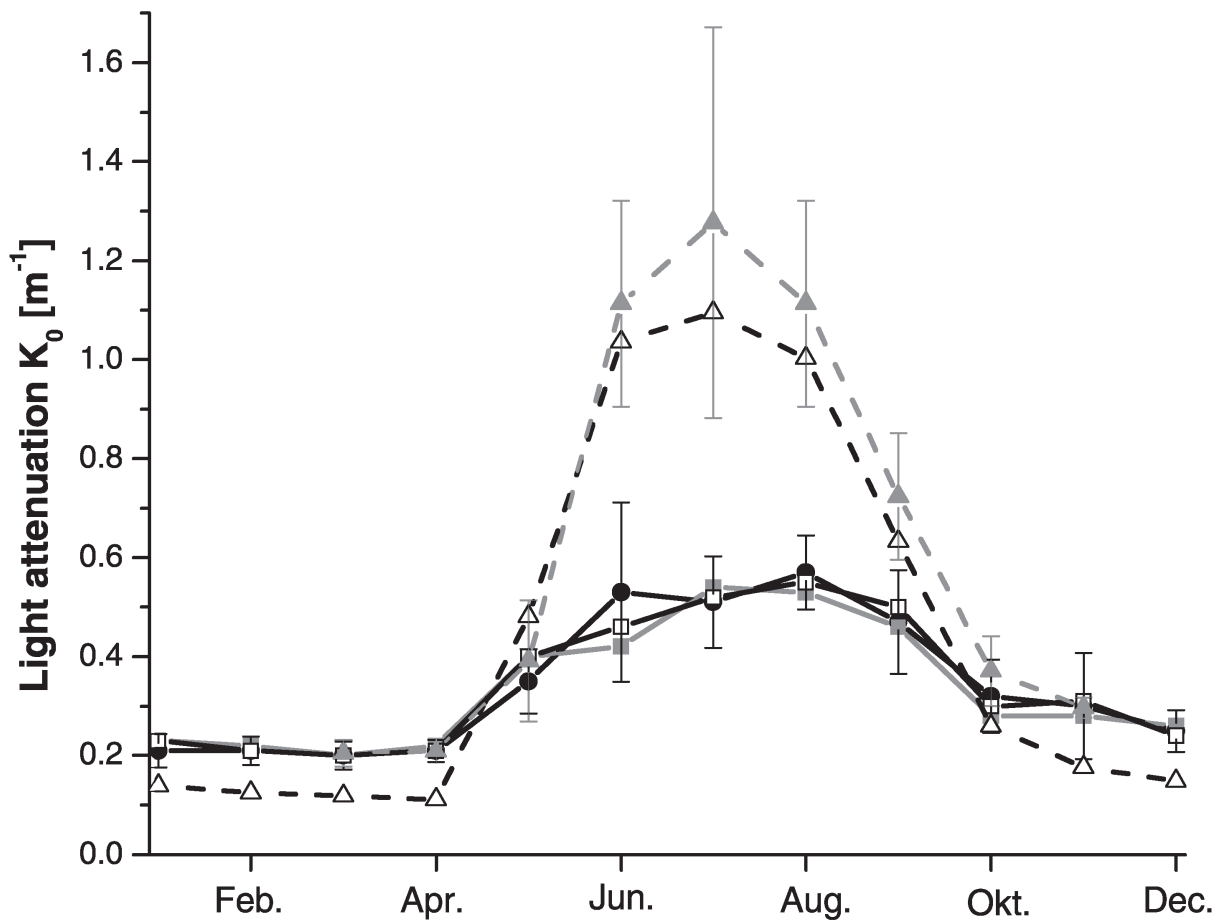

Figure 6. Comparison of current light attenuation $\mathrm{K}_{0}$ (solid lines) and under conditions without upstream hydropower operation (dashed lines). Values depict monthly averages of attenuation for 1999 to 2004 and are compared to $\mathrm{K}_{0}$ derived from light measurements (black circles), measured Secchi depth (grey squares) and particle concentrations (white squares). Corresponding attenuation without dams is derived from measured pre-dam Secchi depths (grey triangles) and modeled no-dam particle concentrations (open triangles). The error bars represent the standard deviations (SD) of monthly-averages.

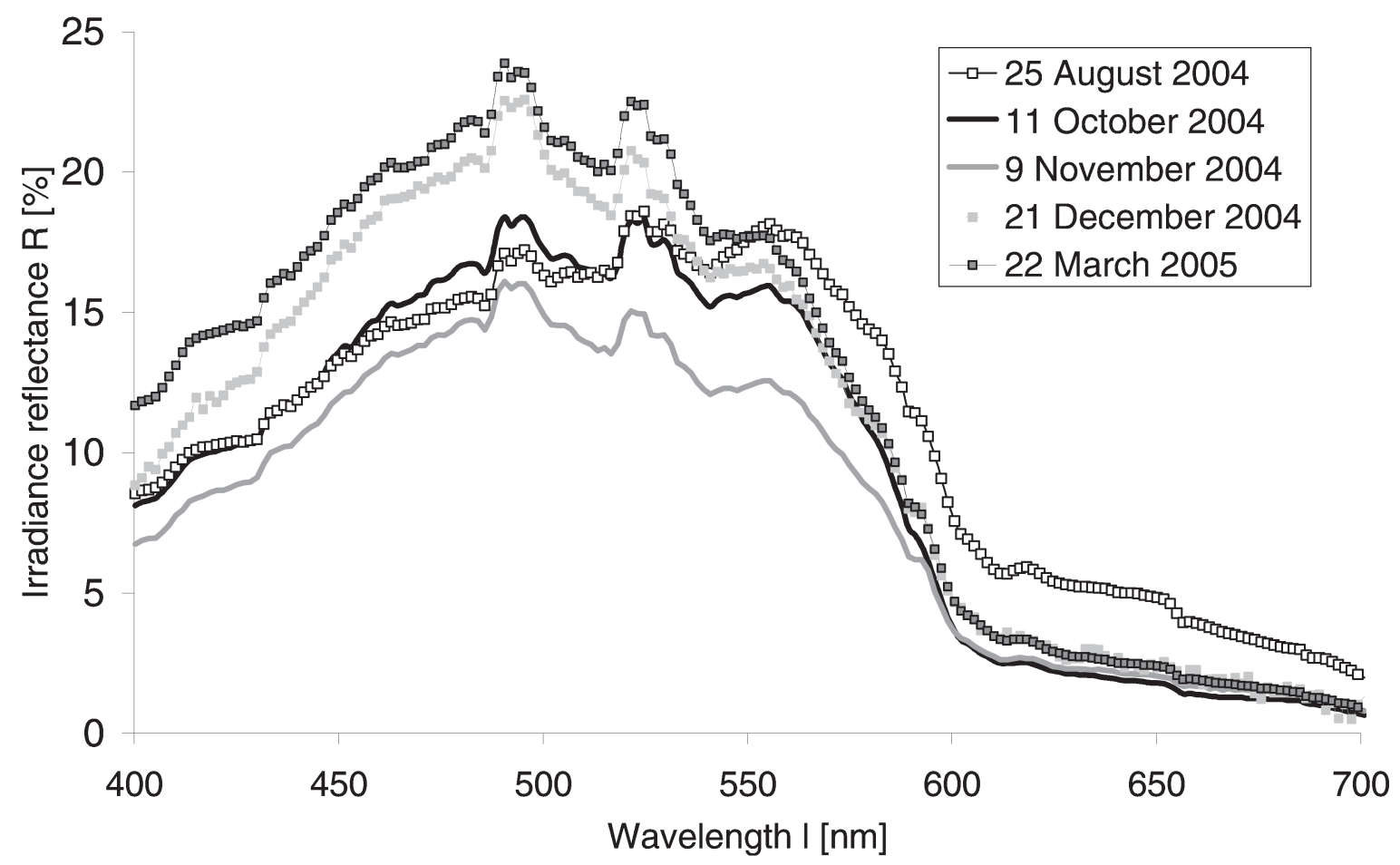

Figure 7 Average reflectance R in the top $8 \mathrm{~m}$ of Lake Brienz, measured on five occasions from August 2004 to March 2005. 


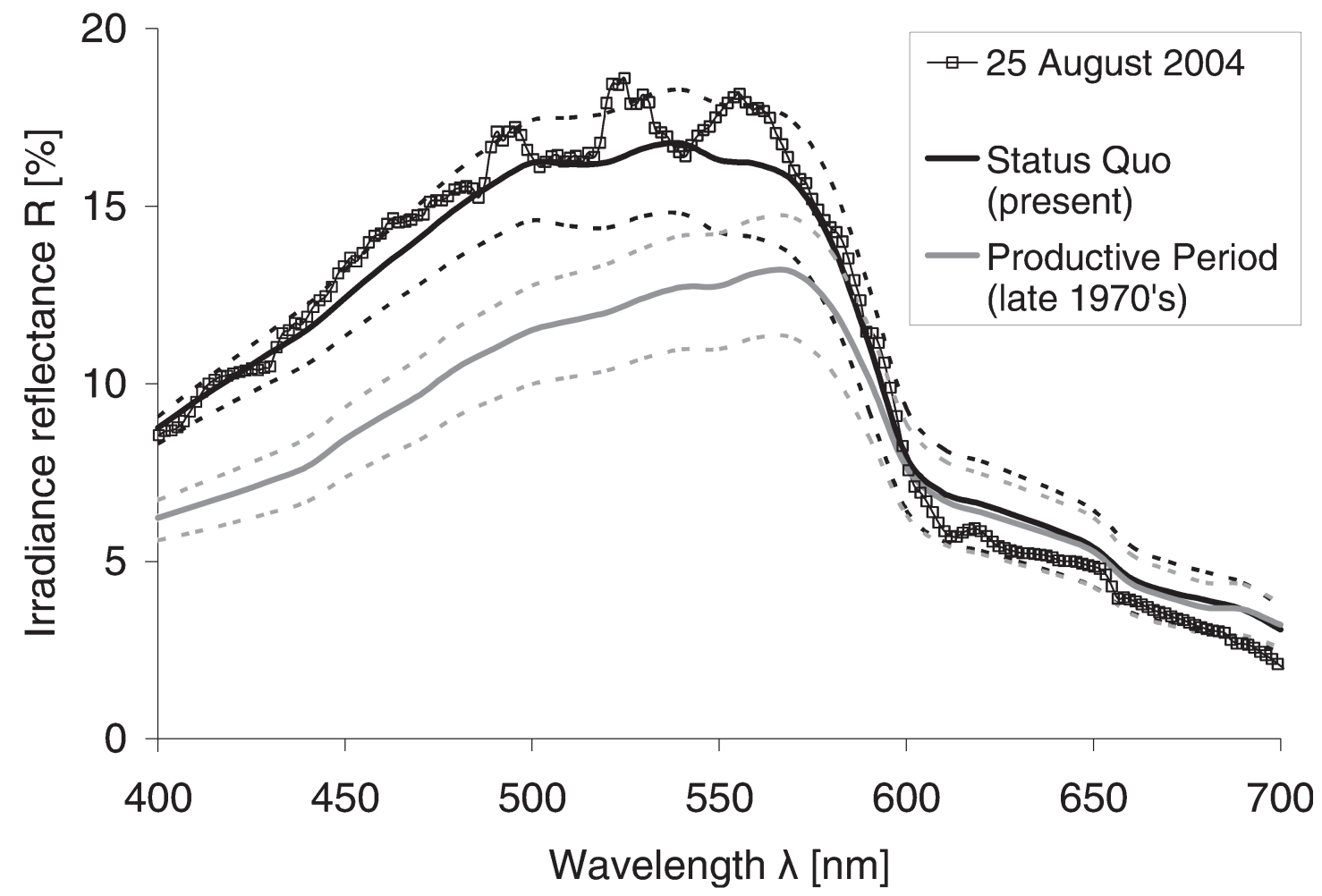

Figure 8. Comparison of current reflectance R (black lines) and under conditions in the late 1970s with presumed 4-fold Chla and DOC levels (grey lines). Black squares illustrate measured reflectance in Lake Brienz on 25 August 2004, bold lines stand for modeled reflectance in summer. The dashed lines indicate the range of modeled variations for altered $\mathrm{C}$ of $\pm 1 \mathrm{mg} \mathrm{L}^{-1}$.

\section{Discussion}

\section{Present light conditions in Lake Brienz}

The present light regime in Lake Brienz is defined predominantly by fine inorganic particles originating from its glaciated catchment. These small particles induce attenuation mainly by scattering and less by absorption, causing the turbid appearance of the water. Since productivity is low, organic substances like Chla and gilvin are of minor relevance for the optical properties. Consequently, absorption contributes only $\sim 5 \%$ to beam attenuation. The remaining $\sim 95 \%$ of attenuation is by scattering and causes a high reflectance. Accordingly, water clarity is low with Secchi depths of $\sim 2 \mathrm{~m}$ in summer and $\sim 6 \mathrm{~m}$ in winter.

Secchi depths are often used as a surrogate for attenuation, as they are easy to measure. For Lake Brienz, we found a correlation between attenuation and Secchi depth similar to the relation in Koenings and Edmundson (1991) derived for turbid waters. In contrast, other studies (Cristofor et al., 1994; Armengol et al., 2003; Reinart et al., 2003) reported steeper slopes, $\alpha_{1}$, in equation (13). The reason for this is most probably due to lower scattering, as variations in $\alpha_{1}$ reflect changes in the proportions of absorption to scattering (Effler, 1996). The intercept, $\beta_{1}$, of $0.22 \mathrm{~m}^{-1}$ (summer) and $0.11 \mathrm{~m}^{-1}$ (winter) is an empirical correction, accounting for the heterogeneity of the vertical particle distribution (Fig. 4). Although, the use of $\overline{\mathrm{C}}\left(\mathrm{z}_{50}\right)$ is not an ideal proxy for the surface particle content, it is the best possible compromise for the reconstruction of the particle concentration, given the limitations of modeling.

Despite these shortcomings, it was possible to reconstruct attenuation from Secchi depths and particle concentrations. Average attenuations for the status quo scenario, i.e. 0.5 to $0.6 \mathrm{~m}^{-1}$ in summer and $\sim 0.2 \mathrm{~m}^{-1}$ in winter, were predicted. Furthermore, the seasonal short-term variations with maxima of $\sim 0.9$ to $1.2 \mathrm{~m}^{-1}$ after heavy floods in summer and minima of $\sim 0.1 \mathrm{~m}^{-1}$ during exceptional low discharge in the two tributaries were predicted.

Periods of unusual water clarity can be explained by discharge patterns and riverine particle transport. The high attenuation in 1987 (Fig. 5) is explained by the combined particle load of the Aare and Lütschine $\left(450 \mathrm{kt} \mathrm{yr}^{-1}\right)$, which was 1.5 -times the average (Finger et al., 2006) in this particular year. Moreover, the extremely low attenuation from fall 1995 to spring 1997 (Fig. 5) corresponds well with the natural discharge during this period, which was 10 to $40 \%$ below the long-term average (1983 to 2001). In 1996 the annual particle load to the lake was $\sim 100 \mathrm{kt} \mathrm{yr}^{-1}$, a factor 3 below the long-term average (Finger et al., 
2006). During the period of maximum clarity in fall 1995 no rain fell for more than four weeks.

\section{Effect of hydropower on light attenuation}

We reconstructed the expected attenuations based on modeled particle concentrations for hypothetical nodam conditions and on measured Secchi records prior to dam construction to evaluate the effect of upstream hydropower operation on attenuation in downstream Lake Brienz. Since pre-dam Secchi recordings are sparse (data only from 1921,1922 and 1923) and cover a complete annual cycle only in 1922, a large uncertainty remains. Winter and spring Secchi depths vary significantly, with values of 8 to $9 \mathrm{~m}$ (1921) and 5 to $6 \mathrm{~m}$ (1922). These variations can, however, be explained by $25 \%$ above-average discharge in 1922 and $25 \%$ below-average discharge in the first half of 1921.

Compared to the status quo scenario, attenuation in Lake Brienz would double during summer without dams, since particles would not be retained in the upstream reservoirs. This result is supported by Secchi recordings in the 1940s (inter-dam period), when Secchi depths in summer show values between nodam conditions and status quo. Without dams, attenuation in winter would drop to half the present values due to low and almost particle-free natural discharge. These effects can even be observed when the Secchi depth from recent years, characterized by extraordinary climatic conditions (e.g. flood in 1999, heat wave in 2003 and flood in 2005), are considered in the assessment. Although such short-term climatic conditions can overrule the effects of hydropower operations, the effects of hydropower operations prevail over the long term.

\section{Effect of oligotrophication on reflectance}

We infer that the relative contribution of absorption and scattering remained approximately the same from pre-dam to the status quo conditions. Since we expect that the phosphorus level prior to eutrophication is about the same as after oligotrophication (Müller et al., 2007), productivity and subsequently the concentration of organic substances are thought to be similar for pre-dam and status quo conditions. However, for the productive decade (late 1970s) - when more organic material was available - we lack an optical model for the multicomponental waters of that period. Optical data is only available for 1985 to 1987 (Kirchhofer, 1990), and therefore only semi-quantitative estimations of the attenuation and the light regime are possible for the productive late 1970s. However, we do not expect a large effect by the higher content of organic compounds, as presently the organic material contributes only $5 \%$ to attenuation.
Although this contribution was surely larger in the late 1970s, it was still low and partly compensated by lower particle concentrations due to enhanced bio-induced sedimentation (Chanudet and Filella, 2007).

To quantify the change in perceived turbidity, we parameterized reflectance for summer as a function of particle concentration, Chla, DOC and their optical properties found in the literature. Due to the natural variability of the governing concentrations, the calculated reflectance has a large uncertainty but matches with the measured reflectance on 24 August 2004 (Fig. 8). Therefore, the relative changes in reflectance due to oligotrophication are expected to be reasonable.

Kallio (2006) presents a decrease of reflectance and shift of maximum values to shorter wavelength for the transformation from eutrophic to oligotrophic conditions due to the decrease of optically active constituents. However, it is likely that reflectance in Lake Brienz was lower during the productive decade since both higher concentrations of light-absorbing organic constituents and lower concentrations of lightscattering particles reduced reflectance. In the last few summers increased glacial melting elevated the fraction of the finest particles, also causing higher reflectance (Wozniak and Stramski, 2004). Therefore, the increase in turbidity in the last decades, as perceived by fishermen and residents, can well be explained by higher reflectance caused by less absorption per attenuation as a result of oligotrophication.

\section{Conclusions}

Based on simulations and measurements of light attenuation and reflectance under status quo conditions, during the eutrophication phase in the late 1970s, and under hypothetical conditions without hydropower in the catchment of the Aare, the following conclusions can be drawn:

(1) Damming in the upstream catchment has significantly changed the seasonal particle flux to downstream Lake Brienz by reducing input during summer and enhancing input during winter. As a result, the present attenuation in summer ( 0.5 to $\left.0.6 \mathrm{~m}^{-1}\right)$ is about half the attenuation without dams (1 to $\left.1.2 \mathrm{~m}^{-1}\right)$. In contrast, during winter the present attenuation $\left(\sim 0.2 \mathrm{~m}^{-1}\right)$ is approximately twice its value for 'no-dam' conditions $\left(\sim 0.1 \mathrm{~m}^{-1}\right)$. These results are supported by the agreement of the simulated particle concentrations with Secchi depths measured since the 1920s.

(2) Strong inter-annual and short-term fluctuation of attenuation, especially in spring and fall, is a direct consequence of variability in the natural discharge 
regime. Extremely low attenuation, such as in fall 1995 $\left(\sim 0.15 \mathrm{~m}^{-1}\right)$, was caused by exceptionally low discharge. Conversely, maximum attenuation was measured after heavy floods such as in August 2005 (0.9 to $\left.1.2 \mathrm{~m}^{-1}\right)$. As a result, light attenuation can temporarily reach minimal and maximal values similar to those of no-dam conditions.

(3) During summer the present reflectance at wavelengths of $550 \mathrm{~nm}$ is $\sim 14$ to $18 \%$. We estimate current reflectance to be $\sim 20$ to $25 \%$ higher than three decades ago during the productive late 1970s when organic compounds were assumed to be 4-fold levels higher. In addition to reduced absorption by less autochthonous organic substances, the biological and chemical sedimentation of fine particles is now also reduced (Chanudet and Filella, 2007). Higher levels of fine particles would enhance scattering and could increase reflectance by another $\sim 20 \%$. These findings are consistent with the subjective observations of increasing turbidity in the last decades by local residents.

\section{Acknowledgments}

This publication is part of an interdisciplinary research project to investigate the effects of catchment alterations on the ecosystem of Lake Brienz. Funding of the study was provided by the Government of Canton Bern, KWO Grimselstrom, Swiss Federal Office for the Environment (FOEN), communities on the shoreline of Lake Brienz and Eawag. Local fishermen have collected Secchi depths on behalf of GBL several times per week since 1993. The remote Sensing laboratory of the University of Zurich provided two GER 1500 radiometers. R. Illi and his crew measured particle concentrations, POC and DOC. S. Robele measured part of the beam attenuation spectra. Furthermore, M. Filella, V. Chanudet and C. Rellstab collaborated in the field and contributed with interesting discussions. Valuable input to an earlier version of this manuscript was provided by Prof. J. Ackerman, Prof. B. Wehrli and two anonymous reviewers.

\section{References}

Aksnes, D. L. and A. C. W. Utne, 1997. A revised model of visual range in fish. Sarsia 82: $137-147$.

Anselmetti, F. S., R. Bühler, D. Finger, S. Girardclos, A. Lancini, C. Rellstab and M. Sturm, 2007. Effects of Alpine hydropower dams on particle transport and lacustrine sedimentation. Aquat. Sci. 69: doi 10.1007/s00027-007-0875-4.

APHA, 1998. Standard methods for the examination of water and wastewater, American Public Health Association, Washington, DC, $2-57-52-58 \mathrm{pp}$.

Armengol, J., L. Caputo, M. Comerma, C. Feijoo, J. C. Garcia, R.
Marce, E. Navarro and J. Ordonez, 2003. Sau reservoir's light climate: relationships between Secchi depth and light extinction coefficient. Limnetica 22: $195-210$.

Arst, H., 2003. Optical properties and remote sensing of multicomponental water bodies, Springer, Praxis-Publisher, Chichester, $231 \mathrm{pp}$.

Babin, M., D. Stramski, G. M. Ferrari, H. Claustre, A. Bricaud, G. Obolensky and N. Hoepffner, 2003. Variations in the light absorption coefficients of phytoplankton, nonalgal particles, and dissolved organic matter in coastal waters around Europe. Journal of Geophysical Research 108: 3211, doi:10.1029/ 2001JC000882.

Baker, E. T. and J. W. Lavelle, 1984. The effect of particle-size on the light attenuation coefficient of natural suspensions. Journal of Geophysical Research-Oceans 89: 4C0622, 8197 - 8203.

Beauchamp, D. A., C. M. Baldwin, J. L. Vogel and C. P. Gubala, 1999. Estimating diel, depth-specific foraging opportunities with a visual encounter rate model for pelagic piscivores. Canadian Journal of Fisheries and Aquatic Sciences 56: 128 139.

Bezinge, A., 1987. Glacial meltwater streams, hydrology and sediment transport: the case of the Grande Dixence hydroelectricity scheme. In: A. M. Gurnell and M. J. Clark (eds.), Glacio-Fluvial Sediment Transfer, Wiley, Chichester, pp. 473 498.

Biggs, B. J. F. and R. J. Davies-Colley, 1990. Optical-properties of Lake Coleridge - the impacts of turbid inflows. New Zealand Journal of Marine and Freshwater Research 24: 441 - 451.

Bricaud, A., M. Babin, A. Morel and H. Claustre, 1995. Variability in the chlorophyll-specific absorption coefficients of natural phytoplankton: Analysis and parameterization. Journal of Geophysical Research 100: 95JC00463, 13321 - 13332.

Bricaud, A., A. Morel and L. Prieur, 1981. Absorption by dissolved organic matter of the sea (yellow substance) in the UV and visible domains. Limnology and Oceanography 26: 43 - 53 .

Chanudet, V. and M. Filella, 2007. The fate of inorganic colloidal particles in Lake Brienz. Aquat. Sci. 69: doi 10.1007/s00027007-0877-2.

Cristofor, S., A. Vadineanu, G. Ignat and C. Ciubuc, 1994. Factors affecting light penetration in shallow lakes. Hydrobiologia 275/ 276: $493-498$.

Davies-Colley, R. J. and D. G. Smith, 2001. Turbidity, suspended sediment, and water clarity: A review. Journal of the American Water Resources Association 37: 1085 - 1101.

Davies-Colley, R. J., W. N. Vant and D. G. Smith, 1993. Colour and clarity of natural waters, Ellis Horwood, New York, 310 pp.

Doxaran, D., N. Cherukuru and L. S. J., 2006. Apparent and inherent optical properties of turbid estuarine waters: measurements, empirical quantification relationships, and modeling. Applied Optics 45: 2310 - 2324.

Effler, S. W., 1996. Limnological and engineering analysis of a polluted urban lake, Springer Verlag, New York, $782 \mathrm{pp}$.

Effler, S. W., R. K. Gelda, J. A. Bloomfield, S. O. Quinn and D. L. Johnson, 2001. Modeling the effects of tripton on water clarity: Lake Champlain. Journal of Water Resources Planning and Management 127: 224-234, doi:10.1061/(ASCE)07339496(2001)127:4(224).

Finger, D., P. Bossard, M. Schmid, L. Jaun, B. Müller, D. Steiner, E. Schäffer, M. Zeh and A. Wüest, 2007. Effects of alpine hydropower operations on primary production in a downstream lake. Aquat. Sci. 69: doi 10.1007/s00027-007-0873-6.

Finger, D., M. Schmid and A. Wüest, 2006. Effects of upstream hydropower operation on riverine particle transport and turbidity in downstream lakes. Water Resources Research 42: W08429, doi:10.1029/2005WR004751.

Flück, H., 1926. Beiträge zur Kenntnis des Phytoplanktons des Brienzersees. Ph.D., ETH

Frauendorf, J., 2002. Entwicklung und Anwendung von Fernerkundungsmethoden zur Ableitung von Wasserqualitätsparametern verschiedener Restseen des Braunkohlentagebaus in Mitteldeutschland. Ph.D., Martin Luther University, Halle, Wittenberg, $261 \mathrm{pp}$. 
Gliwicz, M. Z., 1986. Suspended clay concentration controlled by filter feeding zooplankton in a tropical reservoir. Nature 323: $323-325$.

Goldman, C. R., 1988. Primary productivity, nutrients, and transparency during the early onset of eutrophication in ultraoligotrophic Lake Tahoe, California-Nevada. Limnology and Oceanography 33: $1321-1333$.

Gordon, H. R. and A. Morel, 1983. Remote assessment of ocean colour for interpretation of satellite visible imagery: A review, 4. Springer Verlag, New York, $114 \mathrm{pp}$.

Guenther, M. and R. Bozelli, 2004. Effects of inorganic turbidity on the phytoplankton of an Amazonian Lake impacted by bauxite tailings. Hydrobiologia 511: $151-159$.

Hinderer, M., 2001. Late Quaternary denudation of the Alps, valley and lake fillings and modern river loads. Geodinamica Acta 14: $231-263$.

Hofer, F., 1952. Über die Energieverhältnisse des Brienzersees. Beitr. Geol. Schweiz 7: 95.

Jaquet, J.-M., F. Schanz, P. Bossard, K. Hanselmann and F. Gender, 1994. Measurements and significance of bio-optical parameters for remote sensing in two subalpine lakes of different trophic state. Aquatic Sciences 56: 263 - 302.

Jaun, L., 2005. Lichtregime im Brienzersee. M.S., ETH Zurich

Jeppesen, E., M. Sondergaard, J. P. Jensen, K. E. Havens, O. Anneville, L. Carvalho, M. F. Coveney, R. Deneke, M. T. Dokulil, B. Foy, D. Gerdeaux, S. E. Hampton, S. Hilt, K. Kangur, J. Köhler, E. Lammens, T. L. Lauridsen, M. Manca, M R. Miracle, B. Moss, P. Noges, G. Persson, G. Phillips, R. Portielje, C. L. Schelske, D. Straile, I. Tatrai, E. Willen and M Winder, 2005. Lake responses to reduced nutrient loading - an analysis of contemporary long-term data from 35 case studies. Freshwater Biology 50: $1747-1771$, doi:10.1111/j.1365 2427.2005.01415.x.

Jewson, D. H. and J. A. Taylor, 1978. The influence of turbidity on net phytoplankton photosynthesis in some Irish lakes. Freshwater Biology 8: $573-584$.

Kallio, K., 2006. Optical properties of Finnish lakes estimated with simple bio-optical models and water quality monitoring data. Nordic Hydrology 37: $183-204$.

Keller, P., 2001. Imaging spectroscopy of lake water quality parameters. Ph.D., University of Zurich, $161 \mathrm{pp}$.

Kirchhofer, A., 1990. Limnologische und ichthyologische Untersuchungen im Brienzersee unter besonderer Berücksichtigung der Differenzierung der sympatrischen Felchenpopulationen. Ph.D., University Bern, 99 pp.

Kirk, J. T. O., 1985. Effects of suspensoids (turbidity) on penetration of solar radiation in aquatic ecosystems. Hydrobiologia 125: $195-208$.

Kirk, J. T. O., 1994. Light and photosynthesis in aquatic ecosystems, Cambridge University Press, New York, $481 \mathrm{pp}$

Koenings, J. P. and J. A. Edmundson, 1991. Secchi disk and photometer estimates of light regimes in Alaskan lakes: Effects of yellow color and turbidity. Limnology and Oceanography 36: $91-105$.

Krause-Jensen, D. and K. Sand-Jensen, 1998. Light attenuation and photosynthesis of aquatic plant communities. Limnology and Oceanography 43: $396-407$.

Loizeau, J. L. and J. Dominik, 2000. Evolution of the upper Rhone River discharge and suspended sediment load during the last 80 years and some implications for Lake Geneva. Aquatic Sciences 62: $54-67$.

Morel, A., 1974. Optical properties of pure water and pure sea water. In: N. G. Jerlov and N. Steeman (eds.), Optical aspects of oceanography., Academic Press, London, pp. 1-24.
Morel, A., 1988. Optical modeling of the upper ocean in relation to its biogeneous matter content (Case 1 waters). Journal of Geophysical Research 93: 10,749 - 710,768.

Morel, A. and L. Prieur, 1977. Analysis of variation in ocean color. Limnology and Oceanography 22: $709-722$.

Müller, B., D. Finger, M. Sturm, V. Prasuhn, T. Haltmeier, P. Bossard, C. Hoyle and A. Wüest, 2007. Present and past bioavailable phosphorus budget in the ultra-oligotrophic Lake Brienz. Aquat. Sci. 69: doi 10.1007/s00027-007-0871-8.

Nydegger, P., 1957. Vergleichende limnologische Untersuchungen an sieben Schweizerseen. Beitr. Geol. Schweiz 9: 80.

Pfunder, M., 1994. Artenzusammensetzung und trophische Struktur des Planktons in einem trübstoffbelasteten oligotrophen See. M.S., ETH

Pierson, D. C. and N. Strömbeck, 2001. Estimation of radiance reflectance and the concentrations of optically active substances in Lake Mälaren, Sweden, based on direct and inverse solutions of a simple model. The Science of the Total Environment 268: $171-188$

Pope, R. M. and E. S. Fry, 1997. Absorption spectrum (380 - 700 $\mathrm{nm})$ of pure water. II. Integrating cavity measurements. Applied Optics 36: 8710 - 8723 .

Preisendorf, R. W., 1986. Secchi disk science: Visual optics of natural waters. Limnology and Oceanography 31: $909-926$

Reinart, A., A. Herlevi, H. Arst and L. Sipelgas, 2003. Preliminary optical classification of lakes and coastal waters in Estonia and south Finland. Journal of Sea Research 49: 357-366, doi:10.1016/S1385 - 1101(03)00019 - 4.

Rellstab, C., V. Maurer, M. Zeh, H. R. Bürgi and P. Spaak, 2007. Temporary collapse of the Daphnia population in turbid and ultra-oligotrophic Lake Brienz. Aquat. Sci. 69: doi 10.1007/ s00027-007-0872-7.

Sanden, P. and B. Hakansson, 1996. Long-term trends in Secchi depth in the Baltic Sea. Limnology and Oceanography 41: $346-351$

Schanz, F., 1994. Oligotrophication of Lake Zürich as reflected in Secchi depth measurements. Annales de Limnologie 30: 57 65 .

Schleiss, A. and C. Oehy, 2002. Verlandung von Stauseen und Nachhaltigkeit. Wasser Energie Luft 94: 227 - 234.

Siegenthaler, C. 2003. Veränderungen im Ökosystem Brienzersee - Projekt 3.1, GSA - GBL, Bern

Spinrad, R. W., 1986. A calibration diagram of specific beam attenuation. Journal of Geophysical Research-Oceans 91: 6C0185, $7761-7764$

Swift, T., J. Perez-Losada, S. G. Schladow, J. Reuter, D. Jassby and C. Goldman, 2006. Water clarity modeling in Lake Tahoe: linking suspended matter characteristics to Secchi depth. Aquatic Sciences 68: 1 - 15, doi:10.1007/s00027 - 005 - 0798-x.

Tassan, S. and G. M. Ferrari, 1995. Proposal for the measurement of backward and total scattering by mineral particles suspended in water. Applied Optics 34: 8346 - 8353.

Tyler, J. E., 1968. The Secchi disk. Limnology and Oceanography 13: $1-6$.

Whitlock, C. H., L. R. Poole, J. W. Usry, W. M. Houghton, W. G. Witte, W. D. Morris and E. A. Gurganus, 1981. Comparison of reflectance with backscatter and absorption parameters for turbid waters. Applied Optics 20: 517 - 522.

Wozniak, S. B. and D. Stramski, 2004. Modeling the optical properties of mineral particles suspended in seawater and their influence on ocean reflectance and chlorophyll estimation from remote sensing algorithms. Applied Optics 43: 3489 3503.

To access this journal online: http://www.birkhauser.ch/AS 